\title{
Sequential Extraction and Mobility Factor of Metals in the Urban Soil of Warri-Nigeria (A Case Study of the Environment of Esisi Open Dump)
}

\author{
Helen Ataikiru1 ${ }^{*}$, I. E. Okieimen² \\ ${ }^{1}$ College of Education, Warri, Nigeria \\ ${ }^{2}$ Department of Chemistry, University of Benin, Benin, Nigeria \\ Email: *ataikiru@yahoo.com
}

How to cite this paper: Ataikiru, H. and Okieimen, I.E. (2021) Sequential Extraction and Mobility Factor of Metals in the Urban Soil of Warri-Nigeria (A Case Study of the Environment of Esisi Open Dump). Journal of Environmental Protection, 12, 196-208. https://doi.org/10.4236/jep.2021.123012

Received: January 28, 2021

Accepted: March 21, 2021

Published: March 24, 2021

Copyright $\odot 2021$ by author(s) and Scientific Research Publishing Inc. This work is licensed under the Creative Commons Attribution International License (CC BY 4.0).

http://creativecommons.org/licenses/by/4.0/ (c) (i) Open Access

\begin{abstract}
Sequential fractionation of $\mathrm{Cr}, \mathrm{Zn}, \mathrm{Pb}$ and $\mathrm{Mn}$ in soil samples collected $5 \mathrm{~m}$ $104 \mathrm{~m}$ away from Esisi open dump was determined to evaluate the potential health danger posed by the metals. Spatial test soil samples were collected at various increasing distances $(5 \mathrm{~m}-104 \mathrm{~m})$ from the epicentre of the dump using a stainless steel auger. Tessier's sequential extraction protocols were employed. The concentrations of the metals in the various fractions were determined, the fractions are exchangeable fraction, carbonate fraction, Fe-Mn oxide fraction, organic fraction and residual fraction. The metals were found mostly concentrated in the Fe-Mn oxide fraction. This study has provided information on the mobility factors and chemical forms of $\mathrm{Cr}, \mathrm{Zn}, \mathrm{Pb}$ and $\mathrm{Mn}$ in the soil of the environment of Esisi open dump and the environmental risk of the metals in the environment of Esisi open dump.
\end{abstract}

\section{Keywords}

Environment, Open Dump, Health Risk, Fraction, Mobility

\section{Introduction}

Heavy metals are metals that have atomic number greater than 20 and density greater than $5 \mathrm{~g} / \mathrm{cm}^{3}$ [1]. Basically, heavy metals are unarguably the transition and post transition metals, and the examples which are common in various literatures are lead $(\mathrm{Pb})$, cadmium $(\mathrm{Cd})$, vanadium (v) cobalt $(\mathrm{Co})$, chromium $(\mathrm{Cr})$, copper $(\mathrm{Cu})$, iron $(\mathrm{Fe})$, arsenic $(\mathrm{As})$, nickel $(\mathrm{Ni})$, manganese $(\mathrm{Mn})$, tin $(\mathrm{Sn})$ zinc $(\mathrm{Zn})$, and mercury $(\mathrm{Hg})$. The availability and accessibility of these metals 
and metalloids through natural and anthropogenic pathways remain a major global concern in the ecosystem [1] [2]. The sources of heavy metals in the environment are natural and anthropogenic. Natural sources include parent rocks and metallic minerals. Anthropogenic sources include agriculture (fertilizers, pesticides, herbicides etc.), metallurgy (mining, smelting etc.), energy production (power plant, leaded gasoline etc.) and sewage disposal etc. [3]; solid waste, vehicular emission, irrigation [4] [5].

The waste in the dump therefore comprises of the three principal solid wastes.

1) Municipal solid waste-residential and industrial waste;

2) Mineral solid waste: wastes from mining of minerals and fossil fuels, milling, processing industries;

3) Agricultural solid waste: wastes from animal manure, slaughter houses, crop harvesting.

Warri is a pivot for a lot of human activities. There are industries such as the refining and petrochemical company, gas company, small scale enterprises which include mechanic workshops, welding workshops, agro-based industries, construction company, etc. There are also numerous shops, malls, markets and houses, all these generate both degradable and non-degradable solid wastes.

Warri is one of the most commercial, industrial and populous cities in Nigeria resulting in enormous production of waste which is fed into open dumps. The human activities in the last decades have contributed to increasing the metal mobility in the environment.

The total concentration of the metal is relevant nevertheless the availability, reactivity and mobility are determined by metal chemical form, making a chemical speciation study necessary [6]. The determination of the total concentration of the metals gives no information on their various forms [7]. Therefore, the determination and monitoring of specific chemical forms of heavy metals in the environmental samples such as airborne particulates, water, biological materials, soils or sediments are extremely important [8].

Metals can be bound in various ways to soil components. For example, they may be adsorbed on clay surfaces, or iron and manganese oxyhydroxides, and/or also present in the lattice of residual primary mineral phases (e.g. silicates) and/or secondary mineral phases, such as carbonates, sulfates and oxides. Metals may also be bound in amorphous materials, such as iron and manganese oxyhydroxides, or complexed with organic matter [9]. Heavy metals in the soil are distributed in the solid and liquid phases, and their speciation in every phase (fraction) depends on several factors.

Tessier's extraction scheme allows the speciation of the total metal content into five fractions: exchangeable bound, carbonate bound, iron/manganese oxide bound, organic matter bound and residual fraction [10]. Tessier's method is selected for sequential extraction or fractionation of metals in soil since it evaluates both the actual and potential mobility of metals in the environment.

The mobility of metals in soil profiles may be assessed on the basis of absolute and relative content of fractions weakly bound to soil components. Mobility 
factor describes the potential mobility of metals in soils as some metal forms are more strongly bound to the soil components than some.

The relative index of metal mobility is calculated as mobility factor [11] using the equation below:

$$
\mathrm{MF}=\frac{F_{1}+F_{2}}{F_{1}+F_{2}+F_{3}+F_{4} F_{5}} \times 100
$$

High MF values are symptoms of relatively high liability and biological availability of heavy metals in soil.

Complexation by organic and inorganic liquids, the oxidation-reduction reactions, adsorption, ion exchange and dissolution-precipitation phenomena are the main processes that determine the metal content in each fraction. Therefore these processes control the mobility and the bioavailability of heavy metals in soils [12]. The bioavailability and mobility of heavy metals largely depend on the form of the heavy metals [13] which can be measured by sequential extraction.

The metals that are separated in the exchangeable fraction are those metals that are retained on the soil surface by relatively weak electrostatic interactions and which can be released by an ion exchange process. The heavy metal fractions that are extracted in the Fe-Mn oxide, organic and residual fractions can be bioavailable to plants when the $\mathrm{pH}$ and redox conditions of the soil changes. Soil properties such as $\mathrm{pH}$, organic matter, particle size, cation exchange capacity (CEC) and Fe oxides have all been shown to have noticeable effect on the bioavailability of heavy metals in the soil and also to influence plant growth [14].

The heavy metals in the exchangeable fraction $\left(F_{1}\right)$ of the soil are absorbed by the root hairs of plants and through food chain get into human beings.

The heavy metals can through seepage and run offs infiltrate into surface water and ground water, which are used for domestic purposes. Heavy metals tend to accumulate in the brain, kidney, liver and immune system where they can severely disrupt normal function [15]. They hinder the catalysts that are responsible for biochemical reactions in the cells of organs such as kidney, liver, brain etc.

Some of these heavy metals are essential micronutrients, but after certain concentrations they pose public health risk. They cause liver damage, kidney damage, diabetes, arteriosclerosis, hypoglycemia, irregular heart rhythm, bronchitis, parkinson's disease (tremor) lung cancer, corrosive action on the skin etc. [16]. This study therefore determines the concentrations of the heavy metals in different fractions of the soil and evaluates the metal mobility factors (MF) as you move away from the open dump to assess the risks of environmental pollution of these metals.

\section{Purpose of the Study}

The purpose of this study is to evaluate the pollution level of the heavy metals in the soil of the environment of Esisi open dump. 


\section{Objectives of the Study:}

This work is set to:

1) Determine the chemical forms of the heavy metals $\mathrm{Cr}, \mathrm{Pb}, \mathrm{Zn}$ and $\mathrm{Mn}$ in the soil samples collected from distance $(5 \mathrm{~m}-104 \mathrm{~m})$ from the epicenter of the Esisi open dump using sequential extraction technique.

2) Evaluate the metal mobility factor (MF\%) of $\mathrm{Cr}, \mathrm{Pb}, \mathrm{Zn}$ and $\mathrm{Mn}$ in soil samples collected from distance ( $5 \mathrm{~m}-104 \mathrm{~m}$ ) of the Esisi open dump.

\section{Experimental}

\subsection{Study Area}

\subsubsection{Study Site and Sampling Location}

Figure 1 shows the geographical location of Warri in the map of Nigeria and Figure 2 shows the Esisi open dump.

Esisi open dump is located in the central area of Warri. It is located in an area near human settlement. The average area of the open dump is $10 \times 27 \mathrm{~m}^{2}$.

Warri metropolis is the headquarters OF Warri South Local Government Area. Warri is situated in the in the Southern part of Delta state precisely about the intersection of longitude $5.45^{\circ}$ North of the Equator. Warri is about 256 square kilometers in the Area, with a total population of 303,417 [17].

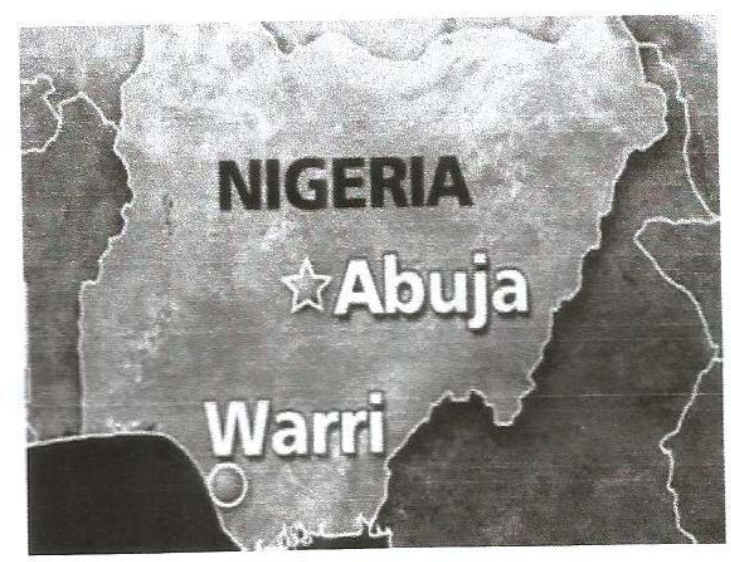

Figure 1. Geographical location of Warri in the map of Nigeria. http://www.tribuneonlineng.com.

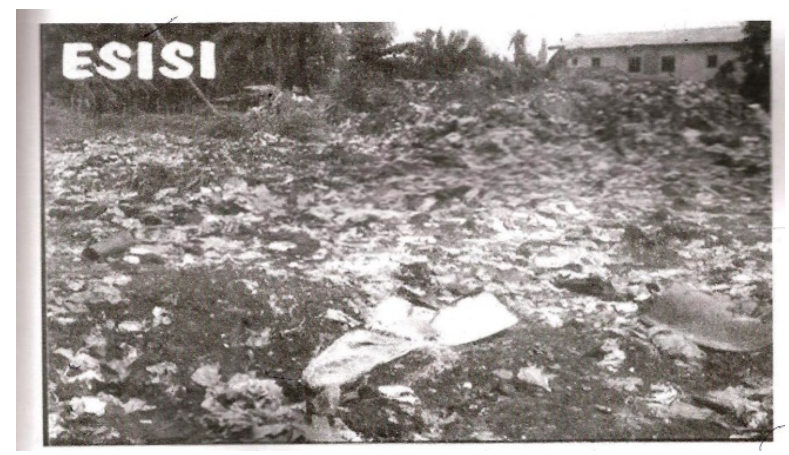

Figure 2. Esisi open dump. 


\subsubsection{Sampling}

Spatial Test Soil Samples

Spatial Test Samples were collected at various increasing distances $(5 \mathrm{~m}-104$

$\mathrm{m}$ ) from the epicenter of Esisi Open dump using stainless steel auger

Sampling was done in the wet season

\subsection{Method}

\subsubsection{Preparation of Soil Samples for Analysis}

The soil samples were air dried, ground and sieved through a $2 \mathrm{~mm}$ sieve. Dried sol samples that fell below the sieve were stored in polythene bags and properly labeled for subsequent analyses. They were used for all the analyses.

\subsubsection{Geochemical Forms $\mathrm{Cr}, \mathrm{Zn}, \mathrm{Pb}$ and $\mathrm{Mn}$}

To be able to access the geochemical forms and bioavailable $\mathrm{Cr}, \mathrm{Zn}, \mathrm{Pb}$ and $\mathrm{Mn}$ in the soil of the open dump Tessier et al. (1979) [10] sequential extraction procedures were employed.

$1 \mathrm{~g}$ of each of the soil samples was used for the sequential extraction. After each successive extraction process (as indicated in Table 1), centrifuging the mixture at $1500 \mathrm{rpm}$ for 15 mins affected the liquid-solid phase separation. The supernatant was decanted into a polypropylene bottle for metal analysis while the residue was carried through the whole extraction process.

The concentrations of heavy metals $\mathrm{Cr}, \mathrm{Zn}, \mathrm{Pb}$ and $\mathrm{Mn}$ in the various extracts were determined in a pre-calibrated atomic absorption spectrophotometer.

\subsubsection{Quality Control and Assurance}

In order to ensure the accuracy and reliability of the results obtained, all reagents used for the preparation of standard solutions and analysis were analytical grades (BDH, Sigma and Buck Scientific).

All glass wares and plastics were acid-washed and rinsed thoroughly with deionized water.

Buck scientific standard solutions were used to calibrate the atomic absorption spectrophotometer as required. Buck scientific (VGP210) atomic absorption spectrophotometer was used for the analyses.

Procedural blank samples were subjected to similar extraction method using the same amounts of reagents. Blank determinations of the elements were below the detection limits of the atomic absorption spectrophotometer.

Table 1. Tessier's et al. sequential extraction of $\mathrm{Cr}, \mathrm{Zn}, \mathrm{Pb}$ and $\mathrm{Mn}$ in the soil samples of the environment of Esisi open dump.

\begin{tabular}{cccc}
\hline Steps & Fractions & Reagents & Durations \\
\hline$F_{1}$ & Exchangeable Fraction & $8{\mathrm{ml} 1 \mathrm{MMgCl}_{2}(\mathrm{pH} 7)}_{1 \mathrm{hr} .}$ & $5 \mathrm{hrs.}$ \\
$F_{2}$ & Carbonate Fraction & $8{\mathrm{ml} 5 \mathrm{MNaOAC}_{2}(\mathrm{pH} 5)}$ & $6 \mathrm{hrs} 96+20 \mathrm{C}$ \\
$F_{3}$ & Fe-Mn Oxide Fraction & $0.04 \mathrm{M} \mathrm{NH}_{2} 0 \mathrm{H} . \mathrm{HCI}$ & $5 \mathrm{hrs} 85+20 \mathrm{C}+30$ mins \\
$F_{4}$ & Organic matter Fraction & $30 \% \mathrm{H}_{2} \mathrm{O}_{2}(\mathrm{pH} 2)$ & Until white fumes appeared \\
$F_{5}$ & Residual & Aqua-regia HC10 & \\
\hline
\end{tabular}


The analyses were carried out in triplicates.

\subsection{Statistical Analysis}

The analytical results were compiled using excel to form a multi-element data base.

\section{Results and Discussion}

The results of the geochemical forms of the metals: $\mathrm{Cr}, \mathrm{Zn}, \mathrm{Pb}$, and $\mathrm{Mn}$ in the soil samples collected at distances $5 \mathrm{~m}-104 \mathrm{~m}$ away from the Esisi open dump are shown in Figure 3, Figure 4, Figure 7 and Figure 9 while the mobility factors ( $\mathrm{MF}$ in \%) of $\mathrm{Cr}, \mathrm{Zn}, \mathrm{Pb}$, and $\mathrm{Mn}$ in the soil samples collected at distances 5 m - $104 \mathrm{~m}$ away from the Esisi open dump are shown in Figure 5, Figure 6, Figure 8 and Figure 10.

The result of chromium in the different fractions (Figure 3) showed that $\mathrm{Cr}$ was mostly concentrated in the Fe-Mn oxide fraction. It was also present in the residual fraction.

The non-residual fractions of $\mathrm{Cr}$ at distance $5 \mathrm{~m}, 6 \mathrm{~m}, 7 \mathrm{~m}, 8 \mathrm{~m}, 9 \mathrm{~m}, 24 \mathrm{~m}, 54$ $\mathrm{m}$ and $104 \mathrm{~m}$ away from the epicentre of the open dump into the people's settlement are $80 \%, 78.7 \%, 78.2 \%, 77.7 \%, 75.7 \%, 77.1 \%, 76.7 \%, 78.3 \%$ respectively as showed in Figure 3. This shows that on the average less than $25 \%$ of $\mathrm{Cr}$ is in the residual fraction, that is more than $75 \%$ are bioavailable.

The percentage chemical forms of $\mathrm{Cr}$ in the soil samples showed that $35.2 \%$ $43.6 \%$ of $\mathrm{Cr}$ was found in the Fe-Mn oxide fraction as shown in Figure 3. That is Fe-Mn oxide fraction had the highest \% of Cr. $6 \mathrm{~m} \& 104 \mathrm{~m}$ away from the open dump had the highest amount about $43.6 \%$ while $54 \mathrm{~m}$ away had the lowest amount of $35.2 \%$. This is consistent with other reporters [18].

The results of $\mathrm{Zn}$ in the different fractions showed that $\mathrm{Zn}$ was also mostly concentrated in the Fe-Mn oxide fraction as shown in Figure 4.

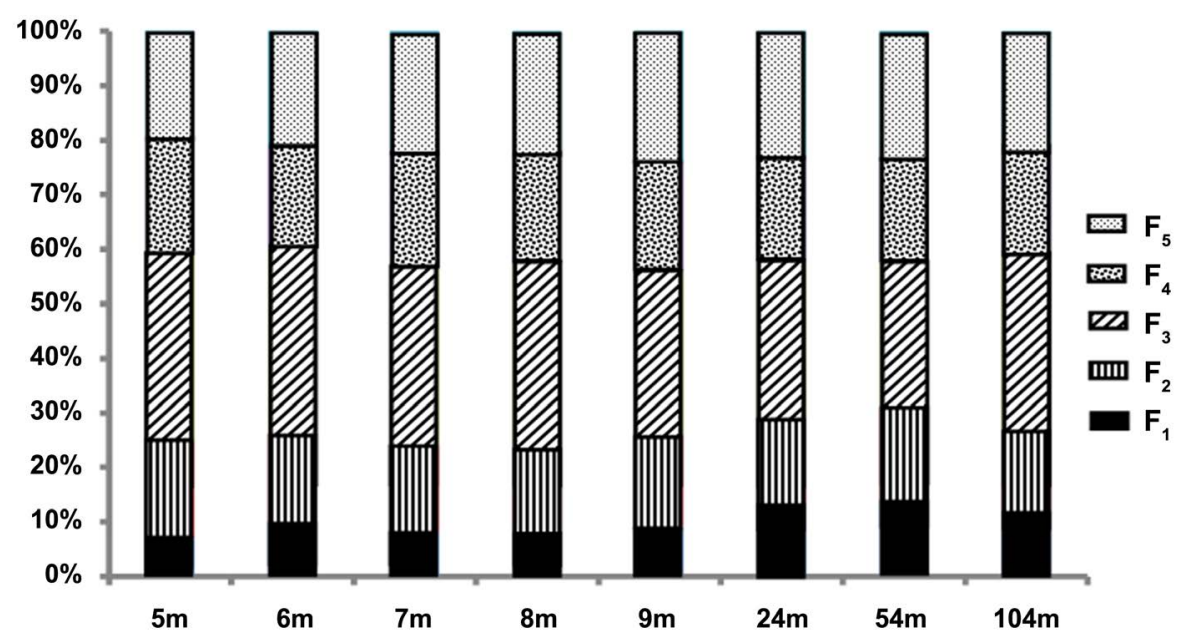

Figure 3. Geochemical forms of $\mathrm{Cr}$ in the soil samples in the environment of Esisi open dump in Warri. 


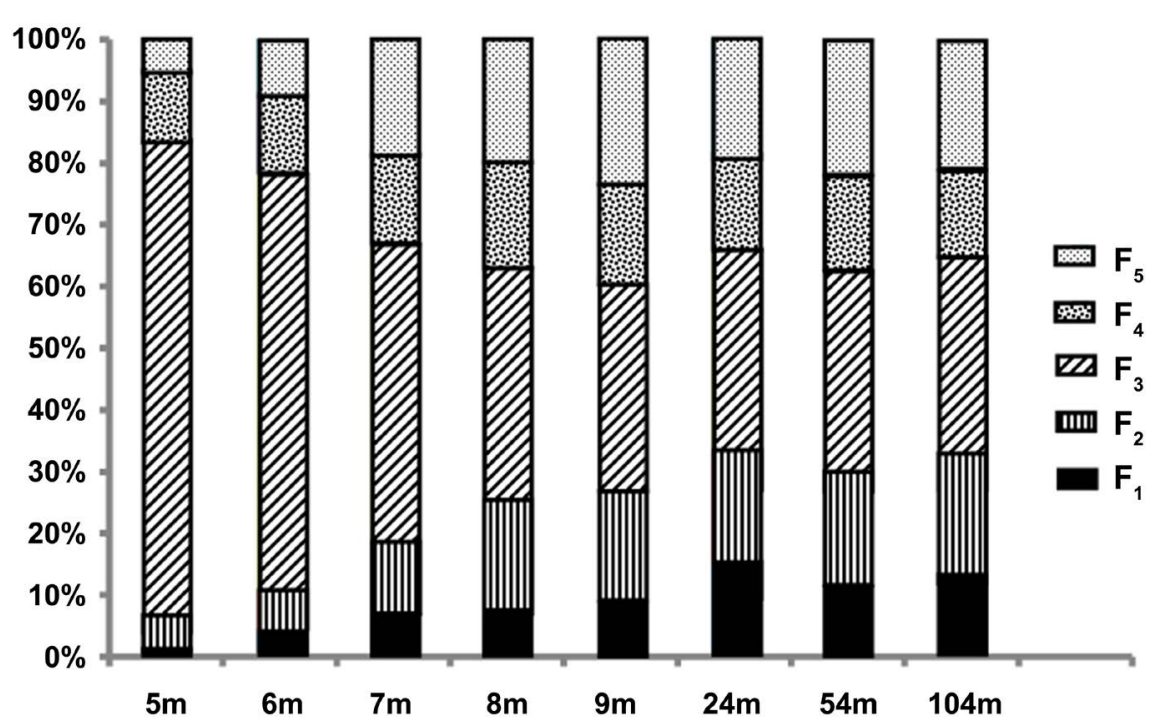

Figure 4. Geochemical forms of $\mathrm{Zn}$ in the soil samples in the environment of Esisi open dump in Warri.

The non-residual fractions of $\mathrm{Zn}$ at distances $5 \mathrm{~m}, 6 \mathrm{~m}, 7 \mathrm{~m}, 8 \mathrm{~m}, 9 \mathrm{~m}, 24 \mathrm{~m}$, $54 \mathrm{~m}$ and $104 \mathrm{~m}$ away from the epicentre of the open dump are $94.7 \%, 91.3 \%$, $80.9 \%, 80.9 \%, 80.2 \%, 75.8 \%, 80.9 \%, 78.3 \%$ and $79 \%$ respectively. The shows that $\mathrm{Zn}$ is more bioavailable in the distance $5 \mathrm{~m}$ away from the epicentre of the open dump.

The result also shows that less than $20 \%$ of $\mathrm{Zn}$ is in the residual fractions while more than $80 \%$ is bioavailable. In all the metals examined in this site, $\mathrm{Zn}$ is the most bioavailable, similar observations have been reported by other researchers [19]

The percentage chemical form of $\mathrm{Zn}$ in the soil samples showed that $31 \%$ $80 \%$ of $\mathrm{Zn}$ was found in the Fe-Mn oxide fraction as shown Figure $4.5 \mathrm{~m}$ away from the open dump had the highest amount $80 \%$, while $104 \mathrm{~m}$ away had the lowest amount of $31 \%$. Fe-Mn oxide fraction had the highest percentage of $\mathrm{Zn}$, followed by the residual by the residual fraction.

The highest percentage of $\mathrm{Zn}$ in the Fe-Mn oxide fraction is consistent with other reporters [18].

The surface of $\mathrm{Fe}$ and $\mathrm{Mn}$ oxide have special affinity for the cations to neutral $\mathrm{pH}$ [20]. Iron and manganese oxides have been implicated in the sequestering of heavy metals in the environment [21]. Fe (ii) and Fe (iii) precipitate as hydroxides at a $\mathrm{pH}>2.0$, while manganese (ii) precipitates at a $\mathrm{pH}>8.6$ [22]. At the coned soil $\mathrm{pH}$ of 5.91, iron rather than manganese species may be the main species responsible for the sequestration of the heavy metals. Fe (ii) and Fe (iii) have been indicated to scavenge metals from soil solution that would normally not precipitate considering both thermodynamic and redox factor [22].

This fraction could be considered relatively stable (slowly mobile and poorly available) but could change with variations in redox conditions becoming more soluble under reducing conditions and less under oxidizing conditions [23]. 
Metals associated with the Fe-Mn oxide and organic fractions can be remobilized and made available to the biota when the $\mathrm{pH}$ and redox conditions of the soil change [24]. The residual fraction had the next highest level of chromium, Exchangeable fraction had 7\% - 10\%, Cr. The soil distance $54 \mathrm{~m}$ and $104 \mathrm{~m}$ away from the open dump had the highest value of $10 \%$. Exchangeable fraction had the least $\%$ of $\mathrm{Cr}$ and $\mathrm{Zn}(1 \%-15 \%)$. As a result, very low concentrations of chromium are mobile and will pass into the soil solution. This fraction is important because of the high mobility of metals from it to the aqueous phase [22]. Similar observations have been reported by other researchers [25] [26].

$5 \mathrm{~m}$ away from the epicentre of the open dump had the least amount of $1 \%$, while $24 \mathrm{~m}$ away from the epicentre of the open dump had the highest amount of $15 \%$.

The mobility factor of $\mathrm{Cr}$ in the soil samples analyzed is shown in Figure 5. The MF values ranged from $25 \%$ - 31\% soil sample from distance $54 \mathrm{~m}$ away from the open dump had the highest MF value of $31 \%$, while soil sample from distance $8 \mathrm{~m}$ away from the open dump had the lowest MF value of 23 .

The MF value of $\mathrm{Cr}$ in the soil sample is in the order $54 \mathrm{~m}>24 \mathrm{~m}>104 \mathrm{~m}>9$ $\mathrm{m}>6 \mathrm{~m}>5 \mathrm{~m}>7 \mathrm{~m}>8 \mathrm{~m}$.

The mobility factor of Zinc in the soil samples analyzed is showed in Figure 6. Soil samples from distances $24 \mathrm{~m}$ and $104 \mathrm{~m}$ away from the open dump had the highest MF value of $34 \%$.

The MF value of $\mathrm{Zn}$ in the soil samples distances $5 \mathrm{~m}-104 \mathrm{~m}$ is in the order $24 \mathrm{~m}>104 \mathrm{~m}>54 \mathrm{~m}>9 \mathrm{~m}>8 \mathrm{~m}>7 \mathrm{~m}>6 \mathrm{~m}>5 \mathrm{~m}$.

The non-residual fractions of the metal at the various distances away from the epicentre of the open dump are 55\%, 64.7\%, 52.4\%, 47.4\%, 57.1\%, 57\%, 66.7\% and $70.3 \%$ respectively. This shows that $\mathrm{Pb}$ is more bioavailable in the distance $104 \mathrm{~m}$ away from the epicentre of the open dump.

The percentage chemical forms of lead in the soil samples showed that the residual fraction had the highest amount (30\% - 53\%) as shown in Figure 7. The high level of lead in the residual fraction may be due to the presence of acid resistant

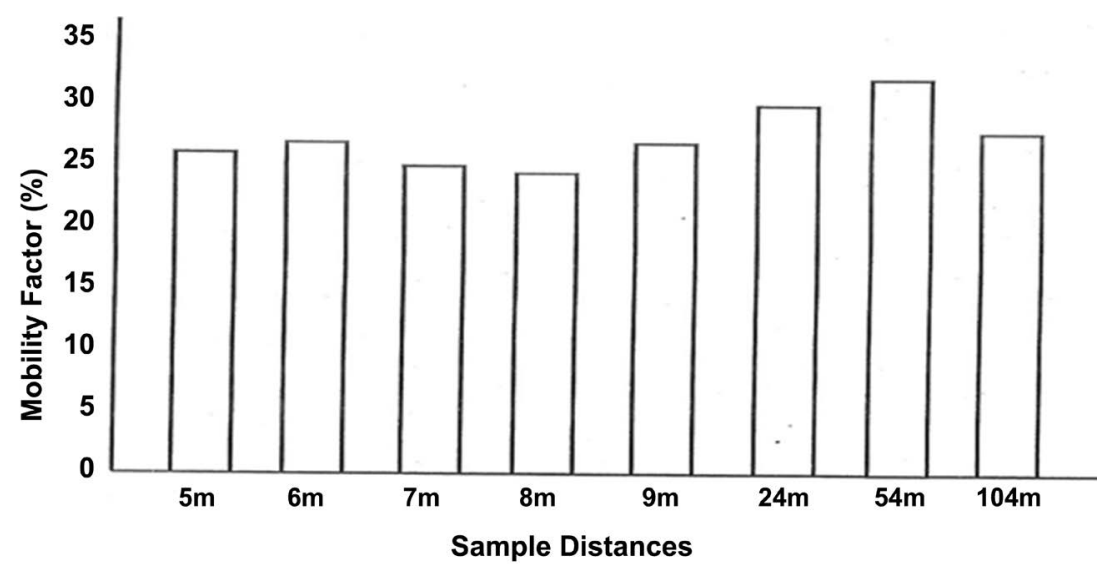

Figure 5. Mobility factor (\%) of $\mathrm{Cr}$ in soil samples at distances (5 m - $104 \mathrm{~m}$ ) of Esisi open dump. 


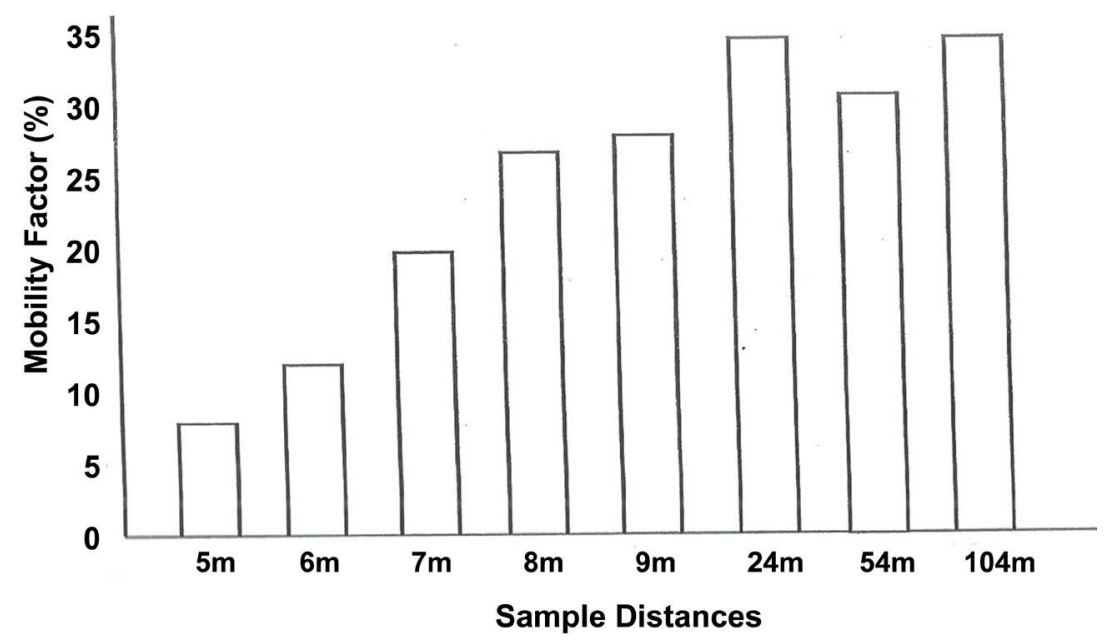

Figure 6. Mobility factor (\%) of $\mathrm{Zn}$ in soil samples of Esisi open dump in Warri.

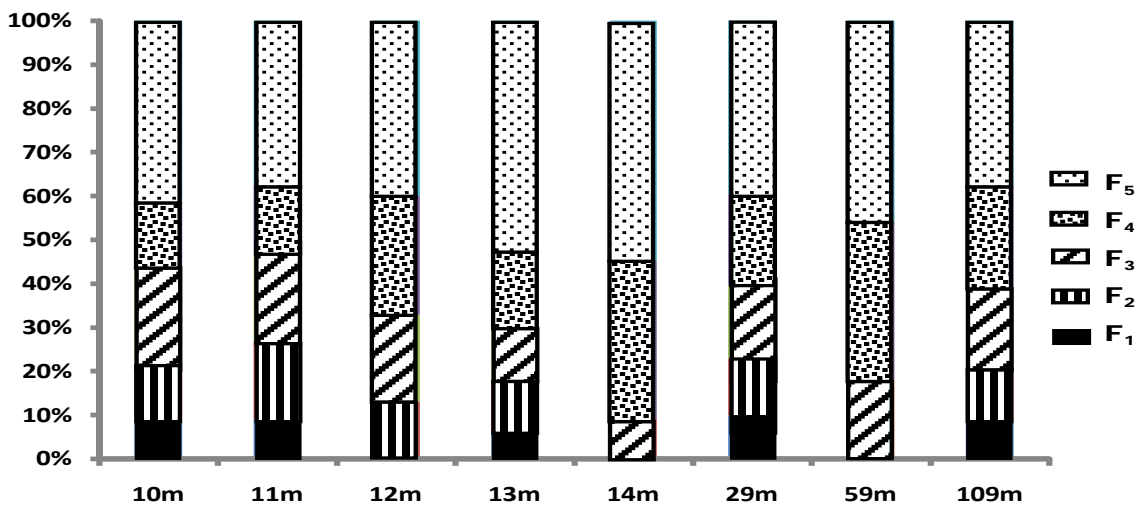

Figure 7. Geochemical forms of $\mathrm{Pb}$ in the soil samples in the environment of Esisi open dump in Warri.

mineral and organic materials. Also the metal may have co-precipitated with various silicate species as a result of their adsorption into the mineral lattice because of the sandy nature of the soil. Similar observations have been reported [19] [24] [27]. $8 \mathrm{~m}$ away from the open dump had the highest percentage of 53\%, while $104 \mathrm{~m}$ away from the epicentre of the open dump had the lowest amount of $30 \%$. Exchangeable fraction had the lowest percentage $\mathrm{Pb}(0 \%-10 \%)$. Similar observations have been reported by other researchers [25] [26]. At distances $6 \mathrm{~m}$, $8 \mathrm{~m}, 9 \mathrm{~m}$ and $104 \mathrm{~m}$ away from the open dump, $\mathrm{Pb}$ was below detection limit.

The content of this $\mathrm{Pb}$ in the exchangeable \& carbonate fractions at distance 8 $\mathrm{m}$ was below detection limit.

The mobility Factor (MF) values of lead range from 14\% - 25\%. The mobility factor of lead in the soil samples analyzed is shown in Figure 8. $54 \mathrm{~m}$ away from the open dump had the highest MF value of $25 \%$. The MF values of $\mathrm{Pb}$ in the soil samples distances is in the order: $54 \mathrm{~m}>104 \mathrm{~m}>24 \mathrm{~m}>5 \mathrm{~m}>8 \mathrm{~m}>9 \mathrm{~m}>7$ $\mathrm{m}>6 \mathrm{~m}$. MF values are increasing as you move away from the open dump.

Figure 9 shows appreciable distribution of $\mathrm{Mn}$ in the exchangeable fraction $\left(F_{1}\right)$ and carbonate fraction $\left(F_{2}\right)$. According to Ramos et al. [28] sequestration of 


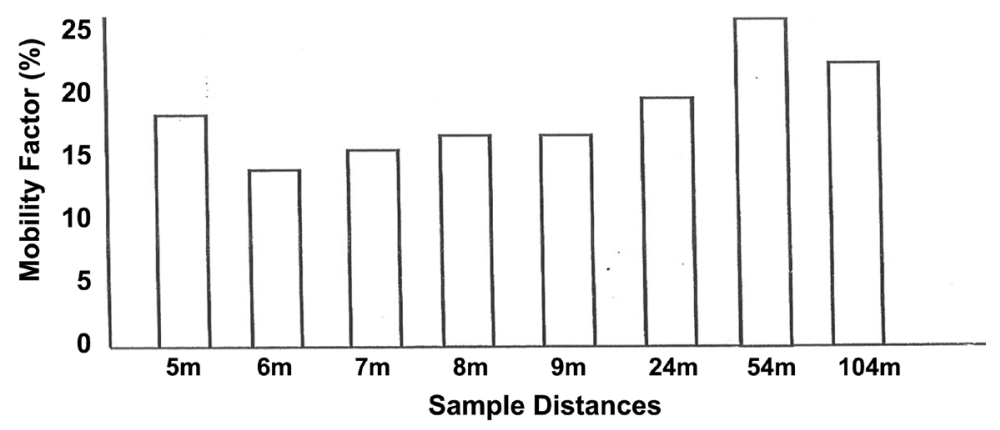

Figure 8. Mobility factor (\%) of $\mathrm{Pb}$ in soil samples in the environment of Esisi open dump in Warri.

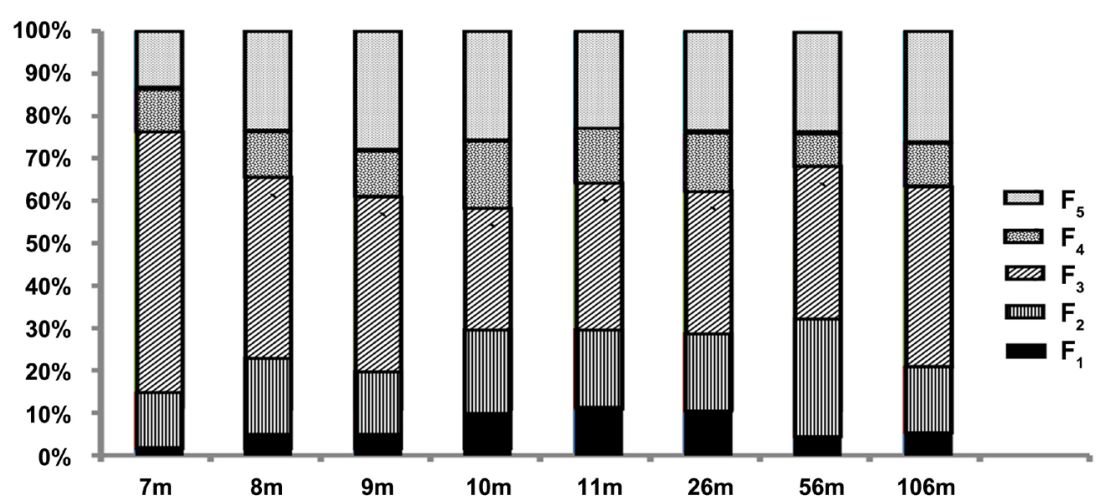

Figure 9. Geochemical forms of $\mathrm{Mn}$ in the soil samples in the environment of Esisi open dump in Warri.

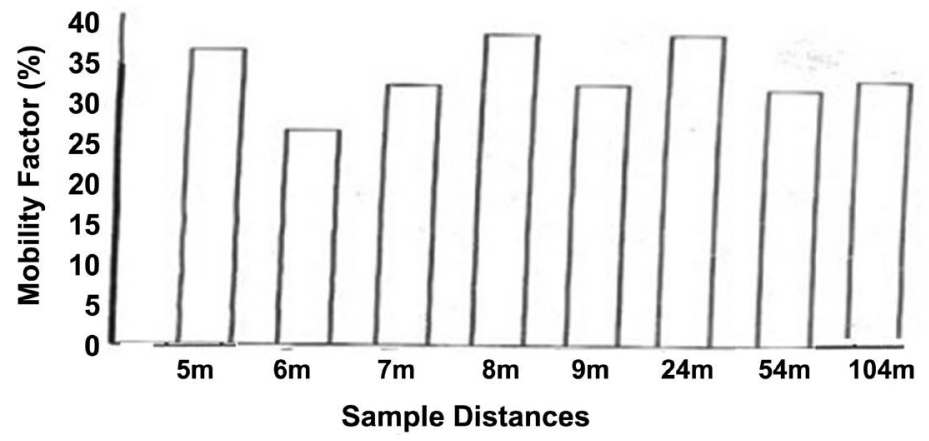

Figure 10. Mobility factor (\%) of Mn in soil samples at distances (5 m-104 m) of Esisi open dump.

heavy metals by carbonate is an important mechanism in the mobility and bioavailability of heavy metals from the environment. 5\% - 23\% of Mn was found in this fraction. $7 \mathrm{~m}$ away from the open dump had the highest amount of $23 \%$ while $8 \mathrm{~m}$ away from the open dump had the least amount of $5 \%$. These results show that about one third of the bioavailable concentrations are mobile and will pass more easily into the soil solution and plants root hairs can easily absorb them. Mn was mostly concentrated in Fe-Mn Oxide fraction. This is consistent with other reporters [18].

The mobility factor of $\mathrm{Mn}$ in the soil samples analyzed is shown in Figure 10. 
Soil samples from distances $8 \mathrm{~m}$ and $24 \mathrm{~m}$ away from the open dump of the highest MF values of $37 \%$. The MF values ranged from $26 \%-37 \%$.

\section{Conclusions}

The geochemical forms of the heavy metals: $\mathrm{Cr}, \mathrm{Zn}, \mathrm{Pb}$ and $\mathrm{Mn}$ examined in this study showed that all the metals were mostly concentrated in the Fe-Mn oxide fraction except $\mathrm{Pb}$. The percentage chemical forms of lead in the soil samples showed that the residual fraction had the highest amount of lead. The high level of lead may be due to the presence of acid resistant minerals and organic materials.

The metals associated with the Fe-Mn oxide and the residual fraction can be remobilized and made available to the biota in the environment when the $\mathrm{pH}$ and redox conditions of the soil change.

Though the exchangeable fractions had low percentages of the metals, this fraction is very important because of the high mobility of metals from it to the aqueous phase.

The MF values for the metals $\mathrm{Cr}, \mathrm{Zn}, \mathrm{Pb}$ and $\mathrm{Mn}$ increase as the distances increase and become far away from the open dump into the inhabitants settlement and surrounding farms.

The MF values are the highest at $54 \mathrm{~m}-104 \mathrm{~m}$ away from the open dump which is the source of the pollution except for Mn.

High MF values are symptoms of biological availability of heavy metals in soils to plants and other ecological receptors.

\section{Acknowledgements}

I wish to acknowledge the head, central analytic laboratory, Nigerian Institute for Oil Palm Research (NIFOR), Benin City, Nigeria for the analytical work. The same acknowledgment also goes to the Tertiary Education Trust Fund (TETFUND) for the grant given towards this research. I will also acknowledge the effort of Okeroghene Ataikiru (BSc. Hons.) for editing and correction of the article.

\section{Conflicts of Interest}

Authors declare no conflict of interest regarding the publication of this paper.

\section{References}

[1] Ali, H. and Khan, E. (2018) Bioaccumulation of Non-Essential Hazardous Heavy Metals and Metalloids in Freshwater Fish. Risk to Human Health. Environmental Chemistry Letters, 16, 903-917. https://doi.org/10.1007/s10311-018-0734-7

[2] Ghaffar Ebadi, A. and Hikmat, H. (2018) Physicochemical Characterization of Sediments from Tajan River Basin in the Northern Iran. Toxicological and Environmental Chemistry, 100, 540-549. https://doi.org/10.1080/02772248.2018.1460929

[3] Odika, P.O., Anike, O.L., Onuvue, M., Odika, N.F. and Ejeckam, R.B. (2020) Assessment of Environmental Geochemistry of Lead-Zinc Mining at Ishiagu Area 
Lower Benue Trough South Eastern Nigeria. Earth Science Research, 9, 31. https://doi.org/10.5539/esr.v9n1p31

[4] Teng, Y., Wu, J., Lu, S., Wang, Y., Jiao, X. and Song, L. (2014) Soil Environmental Quality Monitoring in China: A Review. Environment International, 69, 177-199. https://doi.org/10.1016/j.envint.2014.04.014

[5] Lu, Y., Jenkins, A., Ferrier, R.C., Bailey, M., Gordon, I.J., Song, S., Huang, J., Jia, S., Zhang, F. and Liu, X. (2015) Addressing China's Grand Challenge of Achieving Food Security While Ensuring Environmental Sustainability. Science Advances, 1, e1400039. https://doi.org/10.1126/sciadv.1400039

[6] Ataikiru, H., Okieimen, F.E. and Umumarongie, E.G. (2009) Concentration and Chemical Speciation of Heavy Metals in Urban Soils of Warri, Nigeria. Journal of Industrial Pollution Control, 25, 89-96.

[7] Tokalioglu, S., Kartal, S. and Elci, L. (2000) Determination of Heavy Metals and Their Speciation in Lake Sediments by Flame Atomic Absorption Spectrometry after a Four Stage Sequential Extraction Procedure. Analytica Chimica Acta, 413, 33-40. https://doi.org/10.1016/S0003-2670(00)00726-1

[8] Das, A. and Chakraborty, R. (1997) Electrothermal Atomic Absorption Spectrometry in the Study of Metal Ion Speciation. Fresenius Journal of Analytical Chemistry, 357, 1-17. https://doi.org/10.1007/s002160050102

[9] Gismera, M.J, Lacal, J., Silva, P., Garcia, R., Sevilla, M.T. and Procopio, J.R. (2004) Study of Metal Fractionation in River Sediments. A Companion between Kinetic and Sequential Extraction Procedures. Environmental Pollution, 127, 175-182. https://doi.org/10.1016/j.envpol.2003.08.004

[10] Tessier, A., Campbell, P.G.C. and Bisson, M. (1979) Sequential Extraction Procedure for the Speciation of Particulate Trace Metals. Analytical Chemistry, 51, 844-851. https://doi.org/10.1021/ac50043a017

[11] Cezary, K. and Bal, R.S. (2001) Fraction and Mobility of Copper, Lead and Zinc in the Vicinity of a Copper Smelter. Journal of Environmental Quality, 30, 485-492. https://doi.org/10.2134/jeq2001.302485x

[12] Elass, K., Laachach, A. and Azzi, M. (2003) Etude de la biodisponibilite des metauxlourds dans les sols agricoles irrigues par des eaux pollutes. Rev Francophone d' Ecologie Ind, 32, 1-6.

[13] Zhong, X., Zhou, S., Zhu, Q. and Zhao, Q. (2011) Fraction Distribution and Bioavailability of Soil Heavy Metals in the Yangtze River Delta-A Case Study of Kunshan City in Jiangsu Province, China. Journal of Hazardous Materials, 198, 13-21. https://doi.org/10.1016/j.jhazmat.2011.10.003

[14] Sungur, A., Soylak, M., Yilmaz, E., Yilmaz, S. and Ozcan, H. (2015) Characterization of Heavy Metal Fractions in Agricultural Soils by Sequential Extraction Procedure: The Relationship between Soil Properties and Heavy Metal Fractions. Soil and Sediment Contamination: An International Journal, 24, 1-15. https://doi.org/10.1080/15320383.2014.907238

[15] Ataikiru, H. and Okieimen, F.E. (2016) Distribution Pattern and Availability of Heavy Metals in Soils in the Vicinity of an Open Dumpsite in Warri, Nigeria. Pollution Research, 35, 459-467.

[16] Ataikiru, H. (2021) Waste "Liability and Asset" for National Sustainability. Inaugural Lecture Series, No. 5 of the College of Education, Warri.

[17] National Population Census, 2006.

[18] Pizzaro, J., Rubio, A.M. and Castillo, X. (2003) Study of Chemical Speciation in Se- 
diments: An Approach to Vertical Metals Distribution in Rapel Reservoir (Chile). Journal of the Chilean Chemical Society, 28, 45-50. https://doi.org/10.4067/S0717-97072003000300009

[19] Zauyah, S., Noorhafizahe, J.B., Fauziah, C.I. and Rosenani, A.B. (2004) Concentration and Speciation of Heavy Metals in Some Cultivated and Uncultivated Ultisols and Inceptisols in Peninsular Makatsua. Supersoil 2004: 3 rd Australian New Zealand Soils Conference, Sydney, 5-9 December 2004.

[20] Zhang, L. and Zhao, G. (1996) Applied Geochemistry, 11, 217-222. https://doi.org/10.1002/jae.3950110202

[21] Nacghtegaal, M. and Sparks, D. (2004) Effect of Iron Oxide Coatings on Zinc Sorption Mechanisms at the Clay-Mineral Water Interface. Journal of Colloid and Interface Science, 276, 13-23. https://doi.org/10.1016/j.jcis.2004.03.031

[22] Asagba, E.U., Okieimen, F.E. and Osakpor, J. (2007) Screening and Speciation of Heavy Metals Contaminated Soil from an Automobile Spare Parts Market. Chemical Speciation and Bioavailability, 19, 9-15. https://doi.org/10.3184/095422907X198022

[23] Horsfall, M. and Spiff, A. (2005) Speciation and Bioavailability of Heavy Metals in Sediment of Dioubu River, Port Harcourt, Nigeria. European Journal of Scientific Research, 6, 20-36.

[24] Osakwe, S.A. and Egharevba, F. (2008) Sequential Fractionation of Cadmium, Copper, Lead and Chromium in Soils around Municipal Solid Waste Dumps in Agbor, Nigeria. J. Chem. Soc. Nig, 33, 139-147.

[25] Kabala, C. and Singh, B.R. (2001) Fractionation and Mobility of Copper, Lead and Zinc in Soil Profiles in the Vicinity of a Copper Smelter. Journal of Environmental Quality, 30, 485-492. https://doi.org/10.2134/jeq2001.302485x

[26] Birch, G., Saika, M. and Owen, C. (2001) The Source of Anthropogenic Heavy Metals in Fluvial Sediments of a Rural Catchment, Cox River, Australia. Water, Air, \& Soil Pollution, 126, 13-25. https://doi.org/10.1023/A:1005258123720

[27] Iwegbue, C.M.A. (2007) Metal Fractionation in Soil Profiles at Automobile Mechanic Waste Dumps. Waste Management Research, 25, 585-593. https://doi.org/10.1177/0734242X07080761

[28] Ramos, L., Hernandoz, L. and Gonzalez, M. (1994) Journal of Environmental Quality, 23, 50-57. https://doi.org/10.2134/jeq1994.00472425002300010009x 